\title{
Corporate political connection as a determinant of corporate governance in Hong Kong
}

BOYCE YUNG

Government Counsel, Department of Justice, The Government of Hong Kong Special Administrative Region

PHILIP LAWTON

Law School, Lancaster University

\begin{abstract}
This article reports a study which uses a unique dataset compiled from listed companies in Hong Kong to demonstrate the relationship between corporate political connection with the corporate structure, ownership background and industry type of companies. The study shows that companies with political connection tend to be larger companies while Chinese family-controlled companies and more regulated companies have a bigher level of political connection. Identifying the inadequacies of the existing theories in explaining corporate governance in Hong Kong, the article suggests adopting corporate political connection as a determinant of corporate governance in Hong Kong and elsewhere.
\end{abstract}

\section{Introduction}

Companies are increasingly aware of the importance of politics. In the modern economy, law and policy have become important factors for the operation and even success of a business. They may either promote or restrict the development of the business. As suggested by Fisch, being politically 'naive' can be commercially costly. Companies therefore need to develop their political strategy and accumulate their political capital in the same way they manage other business assets. ${ }^{1}$

An important way to develop a company's political capital and accumulate political influence is through political connection. Corporate political connection (CPC) can take many forms. In this article, CPC refers to political connection of companies through directors. The board of directors has been regarded as proxy of corporate activities in research. ${ }^{2}$ This is because the board functions as the controlling mind of a company and owes the duty of care to serve in the interest of the company. As the court commented in the dictum of Neville J in Bath $v$ Standard Land Company: 'Directors are the brains and the only brains of the company which is the body, and the company can and does act only through them.' ${ }^{3}$

1 J E Fisch, 'How Do Corporations Play Politics? The Fedex Story' (2005) 58 Vanderbilt Law Review 1495, at 1569-71.

2 A Agrawal and C R Knoeber, 'Do Some Outside Directors Play a Political Role?' (2001) 44 Journal of Law and Economics, 179, at 181.

3 Bath v Standard Land Company [1910] 2 Ch 408. 
While the board of directors acts as the brain in making and supervising decisions necessary for corporate management, ${ }^{4}$ other stakeholders have less dominant roles.

CPC may be in the form of taking formal positions in political bodies or establishing informal relationships with government officials. For the purpose of this article, CPC refers to the former. It is a formal form of CPC through corporate directors through formal appointment or election into government policy-making or advisory bodies. Directors may directly influence policy or law-making through these formal positions which confer the right to information, speech and/or vote in the decision-making process. From a research perspective, formal CPC can be more objectively assessed and measured. The information about such connection is commonly disclosed and easily accessible.

\section{CPC in Hong Kong}

When corporate directors take up political appointments, there are always questions regarding their motives and the consequence of their political involvement on their companies. Many studies revealed that politically connected firms can benefit from favourable government policies and awards of government tenders, resulting in more profits and higher share prices. ${ }^{5}$ Some researchers take a wider perspective of corporate governance and point out that there is a relationship between political systems and corporate ownership structures. For instance, Roe pointed out that in social democratic countries, business owners strive to hold more shares to offset the power they lose in complying with labour policies that favour workers. Thus concentrated structure has been prevalent in these countries. ${ }^{6}$

In democratic countries like the USA, CPC is also concerned with political contributions, campaign finance and lobbyists. ${ }^{7}$ These activities, however, are not as relevant to non-democratic Hong Kong where election campaigns and political contributions are not main entrances for CPC. CPC through political donation is far less popular in Hong Kong and does not cause as much concern. Possibly, companies find it not cost effective to influence public policy through electoral donation in a relatively undemocratic government structure. ${ }^{8}$ In addition, corporate political donation may irritate minority shareholders or politicians when the donation is revealed in the annual audit accounts. In Hong Kong, law does not specifically regulate corporate political donation. Election law only regulates general corrupt and illegal conduct and prohibits improper use of election donations. ${ }^{\text {? }}$

4 L E Mitchell and T A Gabaldon, 'If I Only Had a Heart: Or, How Can We Identify a Corporate Morality' (2002) 76 Tulane Law Review, 1645, at 1657.

5 See, for example, A O Krueger, 'The Political Economy of the Rent-Seeking Society' (1974) 64 American Economic Review, 291, at 303; A O Krueger, 'Virtuous and Vicious Circles in Economic Development' (1993) 83 American Economic Review, 351, at 355; M J Olson, The Rise and Decline of Nations (Yale University Press 1982); M J Olson, Power and Prosperity: Outgrowing Communist and Capitalist Dictatorships (Basic Books 2000); A Shleifer and R W Vishny, 'Corruption' (1993) 108 Quarterly Journal of Economics, 599, at 599-618; and A Shleifer and R W Vishny, 'Politicians and Firms' (1994) 109 Quarterly Journal of Economics, 995, at 995-1025.

6 M J Roe, Political Determinants of Corporate Governance: Political Context, Corporate Impact (Oxford University Press 2003).

7 T K Kuhner, 'The Separation of Business and State' (2007) 95 California Law Review, 2353, at 2354.

8 Here, 'undemocratic' refers to the lack of direct elections in government decision-making bodies. The Chief Executive is elected by an Election Committee with small membership. The top decision-making body, the Executive Council, is composed of the Chief Executive, top government officials and unofficial members appointed by the Chief Executive. Only half of the Legislative Council members are elected by popular votes. Most of the District Board members are elected but the board plays only an advisory role by giving opinions to government at district level.

9 Ss 14 and 15, Elections (Corrupt and Illegal Conduct) Ordinance, Cap 554, the Laws of Hong Kong. 
CPC in Hong Kong takes another form: it is very common for corporations to participate in politics through controllers and directors directly joining public services or indirectly influencing policy-making with their socio-political connections. Needless to say, participation of corporate owners or managers in politics exists elsewhere around the globe. Many political leaders in Western democratic countries were elite business people before being elected to political positions. George W Bush and his father, George H W Bush, both oil company owners and then elected Presidents of the USA, are obvious examples. However, unlike in other parts of the world, in Hong Kong, political leaders - except chief executives and their appointed principal officials - enjoy unique flexibility in their political participation in that they are able to hold their political positions as well as their own fulltime work. For instance, unofficial members in the Executive Council (its relationship with the Chief Executive is equivalent to that of a Cabinet with the Prime Minister in the UK) all serve part time. Over half of these unofficial members are renowned business owners, directors and managers. Besides them, Legislative Councillors, many of whom are from the business sector, can also retain their own full-time work. ${ }^{10}$

This article examines this particular mode of CPC in Hong Kong, representative of a typically non-democratic Chinese society, which is at the same time a major world trade centre with an interestingly complex political background.

\section{Characteristics of CPC companies in Hong Kong}

Three hypotheses are set to examine the characteristics of CPC companies in Hong Kong in relation to structure, ownership and industry types.

\section{HYPOTHESIS 1 (H1): CPC AND NON-CPC COMPANIES ARE STRUCTURALLY DIFFERENT}

It is expected that large-scale companies (i.e. companies with higher capitalisation or total asset value) have more resources for CPC and they are also likely to extract more rents through CPC due to bigger market share than their smaller counterparts. Previous studies have contradictory results over the topic: Faccio's worldwide CPC research finds supportive evidence that $\mathrm{CPC}$ is more widespread among larger corporations. ${ }^{11}$ Faccio investigates $\mathrm{CPC}$ in 47 countries and finds that stock prices increase significantly when a board member of the firm enters politics. Additionally, firm value increases more when that board member is elected prime minister, rather than as a member of the parliament. ${ }^{12}$ Faccio also finds that CPC has more significant impact on company value in countries with more corruption, lower quality of legal environment and less freedom of the press. ${ }^{13}$

Another Thai study shows that if the firm controllers take office in the government, their firms would have a higher market valuation than other firms in the country. The political power of the owners who are political leaders accounts for the extraordinary incremental gain in market valuation and share price of the firms. ${ }^{14}$

There are also studies showing that CPC affects firm value in less corrupt countries. For example, Goldman et al find CPC related to the stock price of the company. Investigating the S\&P 500 companies in the USA, their study finds a positive abnormal stock return following the announcement of the nomination of a politically connected individual to the board. When the Republican won the 2000 presidential election, companies connected to

10 For instance, only 16 out of 60 legislative councillors were full-time legislators in 2008: Annual Report, 2008-2009, The Legislative Council, 94-124, <www.legco.gov.hk/general/english/sec/reports/a_0809.pdf>.

11 M Faccio, 'Politically Connected Firms' (2006) 96(1) American Economic Review 369, at 369-71.

12 Ibid 384-5.

13 Ibid 380.

14 P Bunkanwanicha and Y Wiwattanakantang, 'Big Business Owners in Politics' (2007) SSRN eLibrary, 26-7. 
the Republican Party increased in value, and companies connected to the Democratic Party decreased in value. ${ }^{15}$

Nee and Opper's research of CPC in China, however, shows that while political connections provide the strongest competitive advantage on the market for government contracts, company size does not create a general advantage. This implies that firm size or value and CPC are not necessarily related in China. ${ }^{16}$ Whether the scale of a company matters in Hong Kong CPC is as yet unanswered by the literature.

Also related to corporate structure is its concentration pattern. Plenty of previous studies have discussed the impact of politics on ownership pattern. For example, Roe suggests that social democracies impede diffused ownership, which explains why many developed countries practising social democracy still exhibit concentrated shareholding. ${ }^{17}$ Coffee suggests that America reached dispersed structure mainly because the government allowed 'enlightened self-regulation' of US markets in the late eighteenth century. The 'paternalistic supervision' of markets by governments of other countries, on the other hand, has hindered the development of a dispersed structure. ${ }^{18}$ Gourevitch and Shinn also see the strong impact of interest-group politics on corporate governance. They predict that different coalitions among interest groups, namely owners, managers and employees, lead to different governance outcomes: diffusion or concentration. ${ }^{19}$ With reduced political pressure for minority and labour protection through political activities, it is beneficial for politically connected companies to release some of their shares while still maintaining sufficient controlling power. As this is theoretically probable but not empirically proven, the present study tries to test whether CPC companies do have lower concentration than nonCPC companies in Hong Kong.

Therefore, $\mathrm{H} 1$ tests whether CPC companies are characterised by a significant structural difference from non-CPC companies in terms of scale (as measured by a company's total asset value and capitalisation, the calculation methods of which will be discussed in later sections) and concentration.

\section{HyPOTHESIS 2 (H2): CHINESE FAMILY COMPANIES HAVE MORE CPC THAN OTHER COMPANIES}

Wong anticipates that Chinese family companies will split up over time due to the disintegrative effect of succession. ${ }^{20}$ But the disintegration process of these companies seems to take a longer time than that of other companies as found by Lawton's analysis of windingup petitions of companies in Hong Kong. ${ }^{21}$ In another study, Lawton also notes that the Chinese perception of business as personal and familial property rights will last for

15 E Goldman, et al, 'Do Politically Connected Boards Affect Firm Value?' (2009) 22(6) Review of Financial Studies, 2331, at 2331-4.

16 V Nee and S Opper, 'Political Connections in a Market Economy' (2007) 50 CSES Working Paper Series No 1,30 .

17 M J Roe, 'Political Preconditions to Separating Ownership from Corporate Control' (2000) 53 Stanford Law Review, 539, at 601-2.

18 J C J Coffee, 'The Rise of Dispersed Ownership: The Roles of Law and the State in the Separation of Ownership and Control' (2001) 111(1) Yale Law Journal 5-11.

19 See: P A Gourevitch and J J Shinn, Political Power and Corporate Control: The New Global Politics of Corporate Governance (Princeton University Press 2005), 23, 60, 281 and 295.

20 S L Wong, 'The Chinese Family Firm: A Model' (1985) 36(1) British Journal of Sociology 58, at 69.

21 P Lawton, Modelling the Chinese Family Firm and Minority Shareholder Protection: The Hong Kong Experience 1980-1995' (2007) 49 (5-6) Managerial Law: International Journal of Law and Management, 249, at 266. 
generations if not perpetuity. ${ }^{22}$ Lawton also notes that many large listed Hong Kong firms retain the characteristics of small family businesses such as personalism and paternalism. Chinese Confucian thought endorses family as an economic unit. The Chinese perceive that property rights, including corporate ownership, can be maintained for generations. The Chinese cultural traits described by Lawton have explained why Hong Kong, as a Chinese society, has been dominated by family firms. The stress on personal and family relationships is translated into the unwillingness of family firms to relinquish control even after floatation. ${ }^{23}$

Culturally, Chinese family controllers would be highly resistant in relinquishing their dominance over their companies because Chinese merchants had historically learnt the importance of politics on their businesses. For a very long period in the history of China, merchants lacked political power and were oppressed in society. In imperial China, the emperor had almost unrestrained power to control the economy. According to Rozman, there was virtually no limit for the government to intervene in the economic activities of merchants. ${ }^{24}$ The government's intervention was given further legitimacy by Confucius' thinking which advocates that the government should be entrusted with power to redistribute wealth in society. ${ }^{25}$ It endorses the emperors' dominance over both politics and economy so as to fulfil their obligations to ensure peace, prosperity and justice among people. ${ }^{26}$ Knowing that politics had direct influence on their businesses, Chinese merchants sought to build up stable and close relationships with officials in an attempt to increase their political power and thereby benefit their businesses. They tried to merge their interests with those of state officials, for example, by inviting officials to become business partners. ${ }^{27}$ In so doing, they managed to influence public policy and decision-making in favour of their businesses through unofficial channels. ${ }^{28}$

CPC is a way by which controllers acquire power to maintain dominance. It is therefore hypothesised that Chinese family companies have a generally higher degree of CPC than other companies.

\section{HyPOTHESIS 3 (H3): MORE REGULATED INDUSTRIES HAVE MORE CPC THAN LESS REGULATED ONES}

Faccio finds that CPC is less common in the presence of more stringent regulations that set limits on the business activities of public officials to avoid political conflicts of interest, ${ }^{29}$ which is quite expected. These regulations are imposed on officials irrespective of the type of industry they are connected with. But there are industry-specific regulations set by government on the functioning of individual industries such as stipulated conditions for entry into the industry, amount of capital investment, charges, maximum profit allowed etc. As found by Boubakri et al, companies operating in regulated industries are more likely to be politically connected. ${ }^{30}$ It is anticipated that the more an industry is affected by

22 P Lawton, 'Berle and Means, Corporate Governance: Chinese Family Firm' (1996) 6 Australian Journal of Corporate Law 348, at 372 .

23 Ibid 353-4, 378.

24 G Rozman, The Modernization of China (Free Press 1981), 107-8, 139.

25 X Yao, An Introduction to Confucianism (Cambridge University Press 2000), 138.

26 H G Frederickson, 'Confucius and the Moral Basis of Bureaucracy' (2002) 33(6) Administration \& Society 610 , at 613 .

27 T K Wu, 'An Interpretation of Chinese Economic History' (1952) 1 Past and Present, 1, at 9.

28 The imperial period includes both 'Feng Chien' period (from Ch'in dynasty in $221 \mathrm{BC}$ to the Opium War in 1840) and 'Semi Feng Chien' period (from 1840 to the end of Qing in 1911) as delineated by ibid. 7.

29 M Faccio, 'Politically Connected Firms' (2006) 96(1) American Economic Review 369, at 369.

30 N Boubakri et al, 'Political Connections of Newly Privatized Firms' (2008) 14(5) Journal of Corporate Finance 654, at 672 . 


\begin{tabular}{|l||l|l||l|}
\hline Hypothesis & \multicolumn{2}{|l|}{$\begin{array}{l}\text { Pairs of company groups being } \\
\text { compared }\end{array}$} & Characteristics being compared \\
\hline \hline 1 & CPC companies & $\begin{array}{l}\text { Non-CPC } \\
\text { companies }\end{array}$ & $\begin{array}{l}\text { Corporate structure } \\
\text { - total asset value } \\
\text { capitalization } \\
\text { - ownership concentration }\end{array}$ \\
\hline 2 & $\begin{array}{l}\text { Chinese family } \\
\text { Companies }\end{array}$ & $\begin{array}{l}\text { Non-Chinese } \\
\text { family companies }\end{array}$ & Degree/level of CPC \\
\hline 3 & $\begin{array}{l}\text { More regulated } \\
\text { companies }\end{array}$ & $\begin{array}{l}\text { Less regulated } \\
\text { companies }\end{array}$ & \\
\hline
\end{tabular}

Table 1: Characteristics of company groups under comparison

government policies and monitoring regulations, the more CPC the industry will seek to establish in order to gain the benefits of being close to, or even part of, the regulationsetting authority. It is also anticipated that through hypothesis testing Hong Kong industries that are more attracted to CPC will be revealed.

\section{SUMMARY OF THE HYPOTHESES}

The three hypotheses aim to compare the characteristics of three pairs of contrasting company groups in order to find out whether there are significant differences within each pair of groups in relation to CPC, as summarised in Table 1.

Hypothesis 1 examines whether there are any significant differences in respect of variables related to corporate structure (i.e. total assets, capitalisation and ownership concentration) between companies with and without CPC.

Hypotheses 2 and 3 examine whether there are any significant different levels of CPC between two other pairs of company groups with contrary corporate governance features (namely, Chinese-family verses non-Chinese-family companies, and companies under moreversus-less government regulation).

\section{Methodology}

\section{SAMPLE SELECTION}

Several criteria have been considered in selecting the research sample on which tests are to be conducted:

(a) The sample should be composed of Hong Kong companies to reveal the characteristics of CPC in the local context.

(b) These companies together should play a major role in the Hong Kong economy so that their special features related to CPC may significantly impact on the local society and its economy.

(c) There should be a variety of companies in the sample as regards structure, ownership mode, monitoring mechanism and industry types so that rich research data can be obtained to test the hypotheses formulated.

(d) The sample should provide reliable, transparent and retrievable data for systematic statistical analysis.

Public companies included in the Hang Seng Hong Kong Composite Index (HSHKCI) were found to be the best sample that can satisfy all of the above criteria. They are subject to disclosure requirements under listing regulations and rules and thus can provide readily 


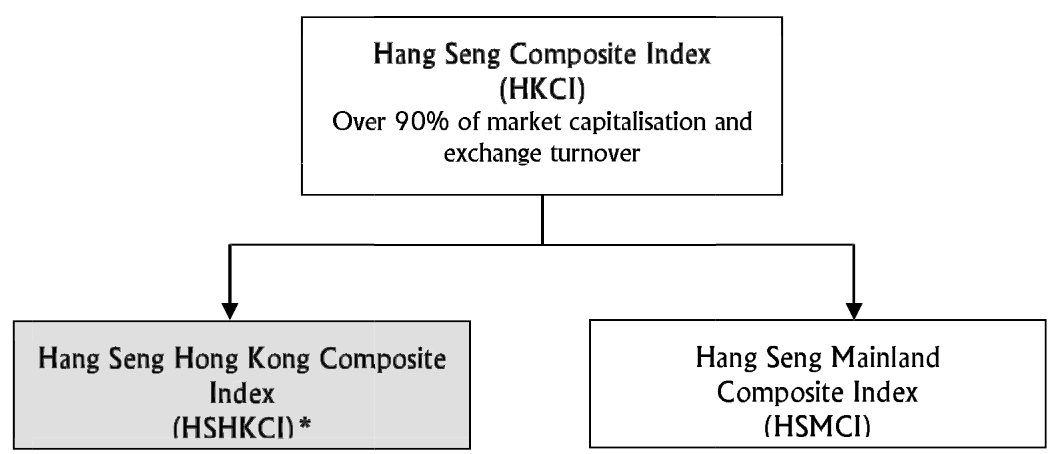

Figure 1: Components of $\mathrm{HSCl}$ as at 31 December 2005

* Sample of the study: $\mathrm{HSHKCl}$

accessible and reliable data not easily obtainable from non-public companies. They are much more varied in different aspects than private companies, which are typically concentrated and controlled by the sole owner or a few business partners. More importantly, the HSHKCI companies are highly representative of the Hong Kong economy, which is characterised by a particularly active stock market where average citizens invest much of their life savings in stock activities.

HSHKCI is the Hong Kong component of the Hang Seng Composite Index (HSCI), which consists of the top 200 listed companies in terms of market capitalisation. The companies comprise over 90 per cent of the market capitalisation and exchange turnover of the stocks listed on the Main Board of the Stock Exchange of Hong Kong. ${ }^{31}$ HSCI is further divided into two sub-indexes: HSHKCI, the chosen sample, which includes HSCI constituent companies listed on the stock exchange of Hong Kong; and the Hang Seng Mainland Composite Index (HSMCI), which includes HSCI constituent companies listed in Hong Kong but with major earnings gained from Mainland China. ${ }^{32}$ HSMCI companies are therefore excluded from the research sample (see Figure 1).

It is important that the reference year of the sample should be set within the past decade to capture the most recent and relevant features of CPC in Hong Kong. It should also be a comparatively stable year financially so that the findings will not be skewed by temporary economic turmoil such as the internet bubble in 2000, the Asian financial crisis in 2003, the stock and property boom in 2007, the financial tsunami in 2008 and the credit and banking crisis afterwards. Amidst the other financially more stable years, 2005 - the middle year of the recent decade - is chosen as the reference year of which corporate data are to be drawn from HSHKCI for analysis.

As at 30 December 2005, HSHKCI represents 55.2 per cent of the market capitalisation and 48.9 per cent of the exchange turnover of the stock listed on the Main Board. ${ }^{33}$ There were altogether 102 companies listed in HSHKCI in 2005. ${ }^{34}$ Among them, Samson Holdings was listed in November 2005 and so did not have complete financial data for the whole year of 2005. In order not to distort the overall statistical analysis, it is excluded from the sample, which ultimately contains 101 companies of HSHKCI in 2005.

31 Press Release, 'HSI Services Announces Index Review Results', HSI Services Limited, 10 February 2006, Appendix 4, at: <www.hsi.com.hk/HSI-Net/static/revamp/contents/en/news/pressRelease/ 20060210e.pdf>.

32 Ibid 3.

33 Ibid. Appendix 5.

34 Ibid. 


\section{DATA COLLECTION}

Full annual reports of the 101 HSHKCI companies published for the financial year of 2005 are used for data collection considering their reliability and accuracy as information sources. Under the Main Board Listing Agreement, a listed company is required to publish an interim report and a full annual report to its shareholders every year within the prescribed time. ${ }^{35}$ The full annual report containing complete financial statements and reports of a company is published at the end of each financial year of the company, either at the end of June or December of each calendar year. Accordingly, the full annual reports of the 101 companies for analysis were published in December 2005 or June 2006. The financial statements contained in these reports were audited and endorsed by qualified accountants following professional accounting standards and stringent requirements prescribed by the Listing Rules. Since the professional accounting standards of Hong Kong are benchmarked against the International Accounting Standards, the figures in the annual reports are comparable domestically and internationally.

All listed companies have now made their annual reports available on their company websites. ${ }^{36}$ Where necessary data are not provided by the annual reports, they are obtained from the 'Company/Securities Profile' webpage of the Hong Kong Exchanges and Clearing Ltd (HKEx). ${ }^{37}$ Relevant data given in both the annual reports and the HKEx website are cross-checked between the two sources to ensure the accuracy of the data used for the study.

The following data are thus collected:

(a) Company profile: the full annual report contains biographies or profiles of members of the board of directors (including executive directors, nonexecutive directors and independent non-executive directors) of a listed company. Information of each of the board members includes:

i) ethnic background;

ii) familial relationship, if any, with other board members;

iii) percentage of shares held;

iv) position(s) held in the company;

v) public and community services;

vi) industry type of each company.

The above information provides useful data for the analysis of Chinese family companies, concentration pattern and industry category.

(b) Financial data: the following financial data of each company as at 30 December $2005^{38}$ are collected from either its annual report or the HKEx website:

35 Rule 13.46(1) of the Main Board Listing Rules provides that an issuer shall send to its members and securities holders an annual report within a prescribed time. Note 1 to the rule further provides that the annual report must be in the English language and must be accompanied by a Chinese translation. Rule 13.48(1) provides that an interim report be issued for the first six months of each financial year. See Rules Governing the Listing of Securities on the Stock Exchange of Hong Kong Limited, ch 13, <www.hkex.com.hk/eng/rulesreg/ listrules/mbrules/documents/chapter_13.pdf >.

36 A listed company must make its annual and interim report available on its website in order to obtain from HKEx a waiver from sending the reports in both English and Chinese to its members: 'The Stock Exchange's Announcement on 17.1.2001', Hong Kong Exchanges and Clearing Ltd, 2001, <www.hkgem.com/ aboutgem/e_release010117.pdf $>$.

37 Investment Service Centre, Hong Kong Exchanges and Clearing Ltd, www.hkex.com.hk/invest/index.asp?id=company/profilemenu_page_e.asp $>$.

38 The date 31 December 2005 was not counted because it was a Saturday, when the stock market was closed. 
i) share price;

ii) number of shares issued;

iii) total assets.

The financial data are used in the calculation of capitalisation and total asset value for the analysis of the scale: capitalisation and total asset value.

\section{DEFINITIONS AND MEASURING METHODS}

The research involves a list of variables that need to be delineated unambiguously with clear definitions and measuring methods in order for tests to be performed on the data. These are as follows.

\section{(a) Chinese family company}

Cox defines a family to mean 'people related by blood or marriage or lifetime commitment', and a family firm to mean 'any enterprise in which more than one family member has a significant investment (financial or emotional) or significant participation in the operation or management decisions of the enterprise'. ${ }^{39}$ However, 'emotional' investment is not always discernible, and whether more than one member of a family has a significant 'financial' investment is not made known in firms held by family trusts. As a matter of fact, many family businesses are held by the company founder, whose family members hold only insignificant amounts of shares. To improve on Cox's definition, the study has adopted only the latter part of it, i.e. only the part on significant participation in corporate decisions is considered. Adding the notion of Chinese ethnicity and making the definition more concise, the term Chinese family company is defined in this study as any enterprise which has a controlling shareholder who is an ethnic Chinese and which has at least two members from the family of the controller sitting on the board.

\section{(b) More regulated industries}

Before distinguishing more regulated industries from less regulated ones, it is necessary to first identify what kinds of industries are involved in the companies under investigation. To this end, the sample of 101 listed companies is categorised into seven industry types by reference to the definitions given by the Heng Seng Industry Classification System (HSICS). ${ }^{40}$ They are: public utilities and transportation; communications; financials; properties and construction; industrial and consumer products; hotels and entertainment; conglomerates and others. While all of them are subject to different kinds of government monitoring regulations, the first four industry types are under particularly close government watch and are highly sensitive to government policies and regulations for various reasons (see Table 2).

It can be seen from the above classification that government regulation is vital to the first four industries in that they either involve scarce resources such as energy and land (in industries (a), (b), (d)) or are costly to people if the systems fail (in industries (c) and (d)).

39 E S Cox, The Family Firm as a Foundation of Our Free Society: Strengths and Opportunities (Cornell University Family Business Research Institute 1996) <www.fambiz.com/Orgs/Cornell/articles/real/ed_cox.cfm>.

40 The HSICS is a comprehensive industry classification system designed for the Hong Kong stock market. Prompted by the listing of a wide variety of companies in different industries in Hong Kong, it meets the need for a detailed industry classification that reflects stock performance in different sectors. HSICS caters for the unique characteristics of the Hong Kong stock market while maintaining international compatibility with mapping to international industry classification systems. See 'Overview: Hang Seng Indexes' $<$ www.hsi.com.hk/HSI-Net/HSI-Net>. 
Table 2: Classification of industries and the respective regulations and policies

\begin{tabular}{|c|c|c|}
\hline & Classification & Regulations and policies \\
\hline 1 & $\begin{array}{l}\text { Public utilities and } \\
\text { transportation }\end{array}$ & $\begin{array}{l}\text { Public utilities include distributors of electricity, gas and water and related } \\
\text { public utilities. Public transportation involves providers and operators of all } \\
\text { kinds of transportation services such as rail and roads facilities and services. } \\
\text { Both kinds of companies provide basic urban living necessities that greatly } \\
\text { influence the everyday life of the general public. Since these companies } \\
\text { enjoy monopoly status in Hong Kong, they are closely monitored by the } \\
\text { government on various business operations and fare level by franchises and } \\
\text { on maximum return or profit by agreements. For example, Kowloon } \\
\text { Motor Bus (1933) Company Ltd (KMB), a subsidiary of Transport } \\
\text { International Holdings, operates the franchised public bus services } \\
\text { provided in Kowloon and New Territories districts according to the terms } \\
\text { and conditions laid down in the franchise granted by the Government of } \\
\text { Hong Kong under the Public Service Bus Ordinance, Cap } 230 \text {. Pursuant to } \\
\text { cl } 25 \text { of the franchise granted to KMB, the Chief Executive in Council may } \\
\text { review the scale of fares to be charged by the company and may } \\
\text { determine and adjust the fares at any time as s/he deems fit. The China } \\
\text { Light and Power (CLP) Holdings Ltd, the electricity monopoly in Kowloon } \\
\text { and New Territories districts in Hong Kong, is regulated by the Hong Kong } \\
\text { government under a Scheme of Control Agreement under which allowed } \\
\text { shareholders are permitted annual return on average net fixed assets of } \\
9.99 \text { per cent for those investments financed by borrowings and for those } \\
\text { financed by shareholders' funds.i. }\end{array}$ \\
\hline 2 & Communications & $\begin{array}{l}\text { This refers to operators of telecommunication networks such as broadband } \\
\text { or mobile service providers and media engaged in broadcasting (e.g. of } \\
\text { television and radio programmes) or publishing (e.g. of newspapers and } \\
\text { magazines) activities. As radio frequency spectrum is a scarce resource, } \\
\text { and the communications industry can exert enormous influence on the } \\
\text { society, the relevant sector is subject to strict licensing requirements for } \\
\text { entering and staying in the business. Publishing companies are relatively less } \\
\text { controlled by the government. But the 'Communications' sector as a } \\
\text { whole is one of the industries under more stringent government scrutiny. } \\
\text { The telecommunications operators are regulated and licensed by the } \\
\text { Telecommunications Authority under the Telecommunications Ordinance, } \\
\text { Cap } 106 \text {, and the broadcasting operators are regulated and licensed by } \\
\text { the Broadcasting Authority under the Broadcasting Authority Ordinance, } \\
\text { Cap 391, the Broadcasting Ordinance, Cap 562, and Part IIIA of the } \\
\text { Telecommunications Ordinance, Cap 106. Under both licensing regimes, } \\
\text { the operators are subject to various statutory requirements and licensing } \\
\text { conditions which cover a wide range of operating matters including } \\
\text { programme content and shareholding change of the controllers. }\end{array}$ \\
\hline 3 & Financials & $\begin{array}{l}\text { Financials refer to banks, insurance companies and other financial service } \\
\text { providers. Like the communications industry, financial institutions are } \\
\text { subject to a stringent regulatory framework so that the government can } \\
\text { ensure that they hold sufficient capital and that savings and investments of } \\
\text { society can be protected. Hong Kong maintains a three-tier system of } \\
\text { deposit-taking institutions, namely, licensed banks, restricted licence banks } \\
\text { and deposit-taking companies. They are collectively known as authorised } \\
\text { institutions. Hong Kong has one of the highest concentrations of banking } \\
\text { institutions in the world. } 68 \text { of the largest } 100 \text { banks in the world have an } \\
\text { operation in Hong Kong. As at February } 2010 \text {, there were } 145 \text { licensed } \\
\text { banks, } 26 \text { restricted licence banks and } 28 \text { deposit-taking companies in } \\
\text { business.ii The Banking Ordinance provides the legal framework for } \\
\text { banking supervision in Hong Kong. As provided in s } 7(1) \text { of the } \\
\text { ordinance, the principal function of the Hong Kong Monetary Authority } \\
\text { (HKMA) is to 'promote the general stability and effective working of the } \\
\text { banking system'. The HKMA monitors closely the continuing development } \\
\text { of banking practices, market environment as well as international } \\
\text { regulatory standards and considers in consultation with the banking }\end{array}$ \\
\hline
\end{tabular}




\begin{tabular}{|c|c|c|}
\hline & & $\begin{array}{l}\text { industry whether any change to the Banking Ordinance is necessary. The } \\
\text { Banking (Amendment) Ordinance } 2005 \text { (BAO 2005) establishes a } \\
\text { legislative framework for implementing the revised capital adequacy } \\
\text { framework released by the Basel Committee on Banking Supervision (Basel } \\
\text { Committee) in Hong Kong. Authorised institutions have to comply with } \\
\text { the provisions of the Banking Ordinance which, among other things, } \\
\text { require them to maintain adequate liquidity and capital adequacy, to } \\
\text { submit periodic returns to the HKMA on the required financial } \\
\text { information, to adhere to limitations on loans to any one customer or to } \\
\text { directors and employees, and to seek approval for the appointment of } \\
\text { directors and chief executives, and for controllers.v }\end{array}$ \\
\hline 4 & $\begin{array}{l}\text { Properties and } \\
\text { construction }\end{array}$ & $\begin{array}{l}\text { This covers a variety of companies related to the property and building } \\
\text { sectors: companies owning and developing properties, producers and } \\
\text { wholesalers of building materials, constructors of commercial and } \\
\text { residential buildings, and providers of services to construction companies. } \\
\text { According to Article } 7 \text { of the Basic Law, land is a state property under the } \\
\text { management of the government in Hong Kong. Properties, either for } \\
\text { accommodation, investment, or both, play a central part in Hongkonger's } \\
\text { lives. Much of people's life savings and monthly incomes are spent on } \\
\text { paying the instalments of their properties. The property sector is greatly } \\
\text { affected by government policies in the areas of land supply, town planning, } \\
\text { property development etc. New land parcels are sold, usually by auction, } \\
\text { for specific developments through long-term land leases. The government } \\
\text { retains the title of the land, and the lessees have the property use, income } \\
\text { and transfer rights." Land sales have historically constituted a significant } \\
\text { portion of government revenues - in some years, proceeds from land sales } \\
\text { could be as much as } 38.2 \text { per cent of total revenues." On average, } \\
\text { between } 1991 \text { and } 2001 \text {, more than } 30 \text { per cent of the HKSAR } \\
\text { government's revenue was related to real estate. } \text {. }^{\text {vi }} \text { The property } \\
\text { development is therefore closely related to government policy. In addition, } \\
\text { the property development is subject to various laws and regulations such as } \\
\text { the Buildings Ordinance and Fire Safety Ordinances administered by the } \\
\text { Buildings Department and Fire Services Department, which ensure the } \\
\text { safety of the properties in Hong Kong. }\end{array}$ \\
\hline 5 & $\begin{array}{l}\text { Industrial and } \\
\text { consumer products }\end{array}$ & $\begin{array}{l}\text { This industry genre comprises the manufacturers and distributors of a wide } \\
\text { range of products: machinery and equipment, electronic parts and } \\
\text { products, vehicles, household goods, clothing and accessories, foods and } \\
\text { drinks, health and personal care services and products, and farming and } \\
\text { fishing goods. }\end{array}$ \\
\hline 6 & $\begin{array}{l}\text { Hotels and } \\
\text { entertainment }\end{array}$ & $\begin{array}{l}\text { This leisure-specific genre is related to hotel operators and management } \\
\text { companies as well as providers of entertainment services, leisure facilities, } \\
\text { photographic services and equipment, restaurants and bars. }\end{array}$ \\
\hline 7 & $\begin{array}{l}\text { Conglomerates and } \\
\text { others }\end{array}$ & $\begin{array}{l}\text { Conglomerates are diversified companies engaged in three or more } \\
\text { businesses classified in different sectors, and others are sporadic companies } \\
\text { engaged in industries not classified elsewhere. }\end{array}$ \\
\hline
\end{tabular}

i Franchise, Transport Department, 2006 <www.td.gov.hk/filemanager/en/content_389/kmb\%20franchise _1.8.2007\%20-\%2030.6.2017.pdf>.

ii Annual Report: Chairman's Statement (China Light and Power Holdings Ltd, 2008) <www.clpgroup.com/ Abt/Res/Pub/ARnSER/Documents/2008/eng/E102.pdf>.

iii Monthly Statistical Bulletin: Number of Authorized Institutions and Local Representative Offices, Hong Kong Monetary Authority <www.info.gov.hk/hkma/eng/statistics/msb/attach/T0301.xls>.

iv Banking Policy and Supervision, Hong Kong Monetary Authority <www.info.gov.hk/hkma/eng/bank/ three_tier/three_tier_f.htm>.

v H X Bao and S Z Zhou, 'The Land Market in Hong Kong: Price Index and the Relationship with the Property Market' (SSRN eLibrary 2008)

vi This happened in 1980-1981. The average for 1947-1948 to 1984-1985 was 20 per cent. In the ten years from 1991-2000, land sale proceeds averaged 12 per cent of government revenues. C Chang et al, Property Market Overvaluation, Toebolds, and the Winners' Curse: Evidence from Hong Kong Land Auctions (SSRN 2007), 7.

vii A Smart and J Lee, 'Financialization and the Role of Real Estate in Hong Kong's Regime of Accumulation' (2003) 79(2) Economic Geography 153, at 154. 
They are overseen closely by regulators and are therefore defined as 'more regulated industries' in this study. As for the other industries, the government relies mainly on market regulation apart from basic laws and guidelines. They are defined as less regulated industries in comparison with the above more regulated group.

\section{(c) Corporate scale}

As explained earlier, the scale of a company is measured by its total asset value and capitalisation. Total asset value - the value of a company's possessions including all its fixed capital (land, building, equipment, raw materials etc.) and liquid capital (money) - is a good yardstick for measuring the scale of a company. ${ }^{41}$ Besides calculating how much capital has been put into the company, another measuring tool for corporate scale is its capitalisation 42 (share price $x$ no of shares issued as at 30 December 2005) - i.e. how valuable the company is in the market in the year under study.

\section{(d) CPC}

In Faccio's study, CPC is identified if 'at least one of [the company's] large shareholders (anyone controlling at least 10 per cent of voting shares) or one of its top directors (CEO, president, vice-president, or secretary) is a member of parliament, a minister, or is closely related to a top politician or party'. ${ }^{43}$ In other words, a company is considered to be politically connected if one of its large shareholders or top directors either holds a political position or is closely related to a top politician or party. This definition of CPC can be further improved.

First, a 'large shareholder' holding 10 per cent or more of voting shares does not necessarily participate in corporate decisions if $\mathrm{s} /$ he is not a board member. Second, directors are collectively responsible for the company. Board decisions are generally arrived at by voting of the whole board rather than by 'top directors' only. Last but not least, being 'closely related' to a top politician or party is a vague concept. Faccio herself admits that 'the necessity of relying on publicly available sources for information on close relationships such as friendship or well-known cases of relationships with political parties produces an incomplete picture'. ${ }^{44}$ While this might be an interesting aspect of CPC for qualitative observation, it is certainly not objectively reliable for her quantitative study or for the statistical analysis of the present study.

For a more reasonable and reliable definition, this study identifies a company as having CPC (i.e. formal CPC) if one or more of its directors occupy formal positions in public service institutions. The term 'director' is broadly defined in statute as 'any person occupying the position of director by whatever name called'. 45 In this study, all directors including executive, non-executive, independent and alternate directors are included for the purpose of calculation of CPC. Shadow directors are not included as they are not disclosed in

41 R S Demsetz and P E Strahan, 'Historical Patterns and Recent Changes in the Relationship between Bank Holding Company Size and Risk’ (1995) 1 Economic Policy Review 2, at 15.

42 The Securities and Exchange Commission of the United States uses the public float of the companies to measure the size of companies to determine whether a company is a smaller reporting company (i.e. a company of less than $\$ 75 \mathrm{~m}$ of capitalisation under Regulation S-K as amended in 2008) which qualifies for less stringent reporting requirements. See also M L Ettredge et al, 'The Effects of Firm Size, Corporate Governance Quality, and Bad News on Disclosure Compliance' (forthcoming) Review of Accounting Studies 30.

43 M Faccio, 'Politically Connected Firms' (2006) 96(1) The American Economic Review 369, at 370-2.

44 M Faccio, Politically Connected Firms (SSRN 2004), 4.

45 S 2, Companies Ordinance, Cap 32, the Laws of Hong Kong. 
company annual reports and it is impracticable to obtain sufficient information to confirm whether someone is a shadow director. ${ }^{46}$

Directors' political connection is considered representative of corporate political connection because they are the people appointed to exercise powers over all business and affairs of the company. ${ }^{47}$ They are also representative of the controlling shareholders' interests because the latter can select their preferred candidates and share the power of the directors through the company's appointment mechanism. The law imposes no restrictions on what a company's memorandum or articles may stipulate in the appointment of directors. ${ }^{48}$ The articles of association normally provide that the first directors are named by the founder of a company. ${ }^{49}$ Subsequent directors are appointed by ordinary meetings. ${ }^{50}$ Controllers, who have controlling shareholding and thus greater decision power at ordinary meetings, are able to appoint their nominated candidates as directors to serve their interests.

As for 'public service institution', McGregor defines the term as a body in society which 'concerns itself with the achievement of public objective and the implementation of public policy. ${ }^{51}$ A company in which directors serve in the following public service institutions is counted as having CPC.

\section{Hong Kong Public Service Institutions:}

- the Executive Council (the highest policy decision-making body of Hong Kong) $; 52$

- the Legislative Council (the law-making body of Hong Kong); ${ }^{53}$

- the Election Committee (a body established by the Hong Kong Basic Law for the election of the Chief Executive); ${ }^{54}$

- statutory bodies (bodies established by statutes, e.g. Hospital Authority, Broadcasting Authority, Equal Opportunities Commission etc);

- public bodies (bodies established by the government for performing specific public functions, e.g. Education Commission, Trade Development Council etc);

- district councils (district level consultative bodies);

- government consultative committees and advisory boards (consultative bodies established by the government for consultation on specific policy areas);

- interest groups (e.g. political parties, trade unions, professional bodies);

Chinese Public Service Institutions:

- National People's Congress (the highest organ of state power);

- Local People's Congresses (regional organs of state power);

46 The term 'shadow director', in relation to a company, means a person in accordance with whose directions or instructions the directors or a majority of the directors of the company are accustomed to act': ibid.

47 Article 82, Schedule 1, Companies Ordinance, Cap 32, the Laws of Hong Kong.

48 R R Pennington, Company Law (7th edn, Butterworths 1995), 713. The Companies Ordinance, Cap 32 provides that any articles may adopt all or any of the regulations contained in Table A, which is a standard article set out in Schedule 1, Companies Ordinance, Cap 32, the Laws of Hong Kong.

49 Article 80, Schedule 1, Companies Ordinance, Cap 32, the Laws of Hong Kong.

50 Article 96, ibid.

51 E B McGregor, Jr, 'The Institution of Public Service' (1982) 42(4) Public Administration Review 304, at 305.

52 Article 43, the Basic Law of Hong Kong.

53 Article 66, the Basic Law of Hong Kong.

54 Article 45 and Annex I (Method for the Selection of the Chief Executive of the Hong Kong Special Administrative Region), the Basic Law of Hong Kong. 


\begin{tabular}{|c|c|}
\hline \multicolumn{2}{|l|}{ CPC in Hong Kong } \\
\hline Level of connection & Score \\
\hline Executive Council Member, Legislative Council Member & 4 \\
\hline Election Committee Member, Statutory Body Member, Public Body Member & 3 \\
\hline District Council Member, Government Consultative Committee Member & 2 \\
\hline Interest group chair/executive member & 1 \\
\hline \multicolumn{2}{|l|}{ CPC in China } \\
\hline Level of connection & Score \\
\hline National & 4 \\
\hline Provincial (including autonomous government) & 3 \\
\hline Municipal/prefecture & 2 \\
\hline District/county township & 1 \\
\hline
\end{tabular}

(a) Score of each director = aggregate score of each director's connection with each level of public service institutions

(b) Score of each company = aggregate score of all directors (each found in (a) above) in each company

Table 3: Scorecard - weighing the level of CPC of companies in Hong Kong and China

- National Committee of Chinese People's Political Consultative Conference (consultative body on major national policies);

- regional committees of Chinese People's Political Consultative Conference (CPPCC) (consultative bodies on major regional policies).

\section{(e) Degree/level of CPC}

Few previous studies have systematically measured the degree of CPC. Besides comparing between CPC and non-CPC companies, i.e. distinguishing the sample companies into politically connected and unconnected ones, this study also tries to gauge the degree of CPC by assigning different weightings to different levels of CPC, as illustrated by the scorecard in Table 3.

The scorecard divides different public service institutions of Hong Kong and Mainland China each into four levels according to the extent of their political influence on public policy and law-making. For example, the Executive and Legislative Councils, being the supreme policy-making and law-making bodies in Hong Kong respectively, represent the uppermost local political authorities. Membership in them implies the highest level of political connection. They are assigned the highest score of 4 . Memberships in institutions of less political influence ranging from statutory bodies to regional consultative committees and interest groups ${ }^{55}$ receive the scores of 3, 2 and 1 respectively. Thus, the different CPC weightings are used to reflect how deeply corporations have penetrated into the core of political power and serve as the measuring tool for the degree of CPC in the study.

In Mainland China, the People's Congress and CPPCC exercise their power at all levels: there are national, provincial, municipal and county congresses and CPPCC committees. Like CPC in Hong Kong, membership at different levels of public service institutions in

55 For interest groups, chairship or executive membership is demanded by the study considering their large number of members and mere membership, who do not have much political influence as do those who hold key positions in the interest groups. 


\begin{tabular}{|l|r|r|r|r|}
\hline \multicolumn{1}{|c|}{ Total asset value } & \multicolumn{1}{c|}{ Count } & Mean (HK\$m) & Mean rank & \multicolumn{1}{c|}{$\boldsymbol{p}$} \\
\hline \hline CPC companies & 80 & 99,389 & 54.35 & \multirow{2}{*}{$0.025^{*}$} \\
\cline { 1 - 4 } Non-CPC companies & 21 & 20,780 & 38.24 & \\
\hline
\end{tabular}

Table 4: Difference in total assets between CPC and non-CPC companies

\begin{tabular}{|l|r|r|r|c|}
\hline Capitalisation & \multicolumn{1}{|c|}{ Count } & Mean (HK\$m) & Mean rank & $p$ \\
\hline \hline CPC companies & 80 & 52,320 & 55.49 & \multirow{2}{*}{0.003 * * } \\
\cline { 1 - 4 } Non-CPC companies & 21 & 9,305 & 33.90 & \\
\hline
\end{tabular}

Table 5: Difference in capitalisation between CPC and non-CPC companies

China are assigned different scores reflecting their extent of influence, ranging from 4 at the national level to 1 at the county level.

\section{Findings}

Results of the tests are presented in the following sections.

\section{CPC AND CORPORATE STRUCTURE}

As mentioned earlier, corporate structure is measured by its scale in terms of total assets and capitalisation and ownership concentration in the study. A statistical comparison of each of these variables between the $80 \mathrm{CPC}$ companies (with CPC score $>0$ ) and 21 non-CPC companies (with CPC score $=0$ ) in the sample of 101 listed companies was conducted to discover any significant differences of corporate structure in the two company groups.

\section{(a) Total asset value}

Data of the total asset value of the companies under comparison are non-parametric. Therefore, U-test was performed and the results shown in Table 4 were obtained.

As seen in Table 4, CPC companies have a much higher average total asset value of $\mathrm{HK} \$ 99,389 \mathrm{~m}$, which is 4.78 times more than the average asset total value of $\$ 20,780 \mathrm{~m}$ of non-CPC companies. U-test results confirm that the mean rank difference is statistically significant at 2.5 per cent. The finding shows that, as expected, CPC companies tend to have larger total assets than non-CPC companies.

\section{(b) Capitalisation}

Total assets measure the scale of a company by the concrete value of its possessions. Another tool to measure company value and thus its scale is capitalisation, the total market value of the issued shares of a company. It represents how valuable the company is in the market and how much market share it occupies and is considered one of the most influential variables in measuring market size in organisational studies. ${ }^{56}$

The data of capitalisation are also non-parametrically distributed. Comparison of the mean ranks of the CPC and non-CPC company groups by U-test demonstrates that their difference in capitalisation is highly significant, as shown in Table 5.

56 M J Chen and D C Hambrick, 'Speed, Stealth and Selective Attack: How Small Firms Differ from Large Firms in Competitive Behaviour' (1995) 38(2) Academy of Management Journal 453, at 455. 
Table 5 shows that CPC companies have a mean capitalisation of HK\$52,320m, which is 5.60 times higher than that of the non-CPC companies (HK\$9,350m). The mean rank difference of the two groups is highly significant at 0.3 per cent.

It is true that all listed companies in Hong Kong are relatively large. The above tests, however, are able to detect significant differences in scale between the CPC and non-CPC listed companies in the sample. The previous studies have contradictory results over whether CPC is more widespread among larger-scale companies. ${ }^{57}$ As little research in Hong Kong corporate literature has focused on the subject before, the research finding of this study, which proves that company scale matters in Hong Kong CPC, can help to fill the literature gap.

It is logical to reason that larger-scale companies have more human and financial resources for CPC. With a bigger market share than smaller companies, they are also likely to extract more rents through CPC. Moreover, holding formal posts in the government and other public service institutions is a symbol of prestigious status in Chinese society, ${ }^{58}$ which is especially attractive to larger companies for maintaining and promoting their brand names. Above all, naturally the more assets a company possesses, the more it is concerned about safeguarding them against unfavourable government policies. A direct way to do so is establish CPC through formal participation in policy-making or consultative institutions so that it can influence government policies affecting its business.

The finding of this study is different from Nee and Opper's research on CPC in China, which finds no relationship between company size and CPC. ${ }^{59}$ It is believed that Hong Kong, though part of China, has different political traditions and practices from China, where company size is a negligible issue in establishing CPC when compared with other critical factors such as 'guanxi' (i.e. personal relationships) and the political background of companies. ${ }^{60}$

\section{(c) Ownership concentration}

Besides company scale, ownership concentration is another aspect of corporate structure for comparison between CPC and non-CPC companies in this study. Berle and Means have provided a classical theory on ownership concentration by categorising companies into five major types according to the level of control. ${ }^{61}$ Applying the classification system to the sample companies investigated in this study, we can see a clear picture of the concentration pattern typical of companies in Hong Kong, as depicted in Table 6.

According to Berle and Means, only Type 5 companies which have no controlling shareholders can be considered 'widely held'. In other words, an overwhelming majority of 98.02 per cent of the listed companies in Hong Kong have concentrated ownership. Even when adopting the broader definition suggested by La Porta et al that counts a company as widely held if no ultimate owner controls 20 per cent or more of its shares (which includes both Type 4 and 5), ${ }^{62}$ still over 91 per cent of the sample companies are classified as concentrated ownership in structure.

57 M Faccio (n 43) 370; Nee and Opper (n 16) 30.

58 Y Li, The Structure and Evolution of Chinese Social Stratification (University Press of America 2005), 23-48.

59 Nee and Opper (n 16) 30.

60 U C Braendle et al, 'Corporate Governance in China: Is Economic Growth Potential Hindered by Guanxi?' (2005) April 25 SSRN eLibrary, 12-13.

61 A A Berle Jr and G C Means, The Modern Corporation and Private Property (Transaction Publishers 1932/1991), 67.

62 R La Porta et al, 'Corporate Ownership around the World' (1998) 54(2) Journal of Finance 471, at 478. 


\begin{tabular}{|c|c|c|c|c|c|}
\hline \multicolumn{2}{|c|}{ Control type } & \multirow{2}{*}{\begin{tabular}{r|} 
Concentration $^{*}$ \\
$>80 \%$
\end{tabular}} & \multirow{2}{*}{\begin{tabular}{c|}
$\begin{array}{c}\text { No of } \\
\text { companies }\end{array}$ \\
2
\end{tabular}} & \multirow{2}{*}{\begin{tabular}{|l|}
$\%$ \\
1.98 \\
\end{tabular}} & \multirow{2}{*}{\begin{tabular}{|r|} 
Accumulated $\%$ \\
1.98 \\
\end{tabular}} \\
\hline Type 1 & Complete control & & & & \\
\hline Type 2 & Majority control & $>50-80 \%$ & 48 & 47.52 & 49.50 \\
\hline \multirow[t]{2}{*}{ Type 3} & Minority control & \multirow[b]{2}{*}{$>20-50 \%$} & \multirow[b]{2}{*}{42} & \multirow[b]{2}{*}{41.58} & \multirow[b]{2}{*}{91.08} \\
\hline & $\begin{array}{l}\text { Control through legal } \\
\text { device }\end{array}$ & & & & \\
\hline Type 4 & $\begin{array}{l}\text { Joint minority } \\
\text { management }\end{array}$ & $>5-20 \%$ & 7 & 6.93 & 98.02 \\
\hline \multirow[t]{2}{*}{\begin{tabular}{|l|} 
Type 5 \\
\end{tabular}} & Management control & $<5 \%$ & 2 & 1.98 & 100.00 \\
\hline & & Total & 101 & & \\
\hline
\end{tabular}

Table 6: Control types of sample companies under Berle and Means' classification * Largest shareholding held by a single shareholder

\begin{tabular}{|l|r|r|r|c|}
\hline $\begin{array}{l}\text { Ownership } \\
\text { Concentration }\end{array}$ & Count & Mean (\%) & Standard deviation & $p$ \\
\hline \hline CPC companies & 80 & 44.22 & 20.40 & \multirow{2}{*}{$0.000 * * *$} \\
\hline Non-CPC companies & 21 & 56.87 & 10.84 & \\
\hline
\end{tabular}

Table 7: Difference in ownership concentration between CPC and non-CPC companies

According to Berle and Means, a company's structure gradually evolves from Type 1 to Type 5, i.e. from concentrated to dispersed ownership, when shareholding is broken up as a result of inheritance or death. ${ }^{63}$ Leech attributes such a change more to intense market competition, when shareholding is broken up as a result of the issuing of more securities for raising capital. ${ }^{64}$ However, both theories seem not applicable to the Hong Kong case. Many large Hong Kong public companies have already experienced death of corporate founders and the rapid economic growth of the 1970s to 1990s when competition was keen and the need for capital investment was great. Yet, corporate ownership remains highly concentrated. In fact, Hong Kong has the highest ownership concentration in Asia. ${ }^{65}$

Despite the overall concentrated ownership structure of Hong Kong companies, it is useful to find out whether CPC further pushes companies towards the concentrated end or significantly lowers the degree of concentration. After all, the relationship between CPC and ownership concentration is a scarcely explored subject in past literature. The data of ownership concentration of the CPC and non-CPC company groups under study being parametric, U-test was conducted with the results shown in Table 7.

As expected, both CPC and non-CPC companies display high degrees of ownership concentration (with on average around half of the company shares owned by the largest controller), which is typical of Hong Kong companies as discussed above. However, the degrees of concentration of the two groups of companies are found to be dissimilar. CPC companies have statistically lower average concentration (44.22 per cent (SD: 20.40)) than non-CPC companies (56.87 per cent (SD: 10.8)). The difference is extremely significant with $p$-value lower than the 0.01 per cent level.

63 Berle and Means (n 61) 66

64 D Leech, 'Corporate Ownership and Control: A New Look at the Evidence of Berle and Means' (1987) 39(3)

Oxford Economic Papers 534, at 537.

65 Gourevitch and Shinn (n 19) 18. 
The finding that CPC companies have significantly lower ownership concentration than non-CPC companies confirms the prediction of the study. Through participating in the development of public policies, controlling owners of CPC companies can greatly amplify their control over other stakeholders (minority shareholders, employees etc.) and even capital markets. As aptly argued by Morck et al, 'political influence is plausibly related to what one controls, rather than what one owns'. ${ }^{66}$ With increased control of the company and the market, controlling shareholders do not need to actually own as big a proportion of shares as their counterparts who have no political connection.

Another probable explanation is related to the scale of CPC companies. As found from the previous statistical analysis, CPC companies are generally larger in scale than non-CPC companies in Hong Kong. In discussing minority expropriation, Lang vividly illustrates how the controlling shareholder of a large corporate group can 'steal' from minority shareholders through pyramiding, which allows him/her to hold only a small portion of shares of different companies but gain majority control of each of the companies. ${ }^{67}$ In another work he co-authored with Claessens and Djankov on the ownership and control of all listed corporations in nine East Asian economies, it was discovered that pyramiding is a common phenomenon in Hong Kong. ${ }^{68}$ Large controlling companies at the top of these pyramids have magnified control despite low ownership. This helps one to understand why the generally large-scale-CPC companies, many of which are involved in pyramiding, have lower ownership concentration than the smaller non-CPC companies.

Some analyses attribute concentrated corporate structure to family ownership. For example, Goo and Weber observe that public companies have typically emerged from companies owned by families. ${ }^{69}$ The owner families regard floatation of their companies' shares as merely a means of raising capital for the companies. Giving up the companies' control has never been the intention of floatation. The owner families will continue to keep a shareholding sufficient for controlling the companies.

The phenomenon of public companies found and controlled by family companies is not unique in Hong Kong but is common around the world. ${ }^{70}$ There is, however, great variation in the degree of ownership concentration in different economies. ${ }^{71}$ It seems that the clinging on to controlling power in the company is less obvious in non-Chinese family companies than in Chinese family companies, as will be discussed in the next section.

66 R Morck et al, 'Corporate Governance, Economic Entrenchment, and Growth' (2005) 43 Journal of Economic Literature 655, at 655.

67 L H P Lang, Governance and Expropriation (Edward Elgar 2005).

68 S Claessens et al, 'The Separation of Ownership and Control in East Asian Corporations' (2000) 58 Journal of Financial Economics, 81, at 92-3.

69 S H Goo and R H Weber, 'The Expropriation Game: Minority Shareholders' Protection' (2003) 33 Hong Kong Law Journal, 71, at 71.

70 A majority of listed companies in Western and Eastern Europe, South and East Asia, the Middle East, Latin America, and Africa are publicly traded companies. See, e.g: M Burkart et al, 'Family Firms' (2003) 58(5) Journal of Finance 2167, at 2167-2201; M Faccio and L H P Lang, 'The Ultimate Ownership of Western European Corporations' (2002) 65(3) Journal of Financial Economics 365, at 365-395; S Claessens et al, 'The Separation of Ownership and Control in East Asian Corporations' (1999) SSRN; La Porta et al (n 62) 471-517; M Pagano and A Roell, 'The Choice of Stock Ownership Structure: Agency Costs, Monitoring, and the Decision to Go Public' (1998) 113(1) Quarterly Journal of Economics 187, at 187-255; A Shleifer and R W Vishny, 'A Survey of Corporate Governance' (1997) 52 Journal of Finance 737, at 738-83. Even in the US and the UK, some of the largest listed companies are controlled by families, for example, Wal-Mart, Ford in the US and J Sainsbury in the UK. See Anonymous, 'The World's 250 Largest Family Businesses' (2004) <www.familybusinessmagazine.com/topglobal.html>.

71 Gourevitch and Shinn (n 19) 18. 


\begin{tabular}{|l|r|r|r|r||r|r|}
\hline $\begin{array}{l}\text { Controllers' } \\
\text { background }\end{array}$ & Count & \multicolumn{1}{|c|}{$\%$} & $\begin{array}{c}\text { Capitaliation } \\
\text { (in HK\$m) }\end{array}$ & \multicolumn{1}{c|}{$\%$} & $\begin{array}{c}\text { Total asset } \\
\text { (in HK\$m) }\end{array}$ & \multicolumn{1}{c|}{$\%$} \\
\hline \hline Chinese family & 67 & 67.68 & $1,795,321$ & 40.98 & $2,848,729$ & 33.96 \\
\hline HK Chinese & 6 & 5.94 & 100,877 & 2.30 & 116,891 & 1.39 \\
\hline $\begin{array}{l}\text { HKSAR } \\
\text { government }\end{array}$ & 1 & 1.01 & 84,616 & 1.93 & 113,666 & 1.36 \\
\hline Mainland Chinese & 7 & 7.07 & 267,600 & 6.11 & $1,144,574$ & 13.65 \\
\hline Taiwan Chinese & 1 & 1.01 & 14,646 & 0.33 & 23,821 & 0.28 \\
\hline British & 7 & 6.93 & $1,832,678$ & 41.83 & $3,824,754$ & 45.60 \\
\hline American & 2 & 2.02 & 12,093 & 0.28 & 8,227 & 0.10 \\
\hline European & 2 & 2.02 & 43,967 & 1.00 & 24,551 & 0.29 \\
\hline Australian & 1 & 1.01 & 8,083 & 0.18 & 2,108 & 0.03 \\
\hline Malaysian & 4 & 4.04 & 91,020 & 2.08 & 138,009 & 1.65 \\
\hline Indonesian & 1 & 1.01 & 9,614 & 0.22 & 18,307 & 0.22 \\
\hline Jewish & 2 & 2.02 & 120,513 & 2.75 & 123,877 & 1.48 \\
\hline & 101 & 100.00 & $4,381,028$ & 100.0 & $8,387,513$ & 100.00 \\
\hline
\end{tabular}

Table 8: Company controllers' backgrounds, total assets and capitalisation

\section{(d) Hypothesis 1 confirmed}

\section{H1: CPC and non-CPC companies are structurally different.}

Statistical findings of total asset value and capitalisation show that CPC companies are of significantly larger scale than non-CPC companies. Findings of ownership concentration also show that CPC companies are significantly less concentrated than their counterparts. These results prove that CPC and non-CPC companies are structurally different in terms of company scale and concentration pattern. $\mathrm{H} 1$ is therefore confirmed.

\section{CPC AND CHINESE FAMILY BUSINESSES}

\section{(a) Chinese family businesses}

Hong Kong-based large companies are commonly Chinese family businesses, as shown in the summary of controllers' backgrounds of the 101 listed companies under study in Table 8.

Due to Hong Kong's background of Chinese ethnicity and British colonialism, local Chinese and British companies together occupy 82.18 per cent (Chinese: 40.98 per cent, British: 41.83 per cent) of the total capitalisation and control 79.56 per cent (Chinese: 33.96 per cent, British: 45.6 per cent) of the total assets of all listed companies under study. The large market share of British companies is attributable mainly to one of its member corporations, the giant HSBC. In terms of number, a great majority of the listed companies in fact have a Chinese background ( 81.20 per cent, $\mathrm{N}=82)$ as shown from the first five rows of controllers' background in Table 8 . Among them, most are Chinese family companies, which represent 67.68 per cent of all companies under study, 33.96 per cent of the total assets, and 40.98 per cent of the total capitalisation.

The above figures show the prevalence of Chinese family companies and the considerable market share these companies occupy in Hong Kong. Previous studies have revealed the cultural characteristic of Chinese family business controllers, who see the 


\begin{tabular}{|l|l|r|r|r|r|}
\hline & \multicolumn{1}{|c|}{ Ownership } & \multicolumn{1}{c|}{ Count } & Mean CPC score & Mean rank & \multirow{2}{*}{$\boldsymbol{p}$} \\
\hline \hline \multirow{2}{*}{ HK CPC } & Chinese-family & 67 & 8.69 & 55.23 & \multirow{2}{*}{$0.040 *$} \\
\cline { 2 - 6 } & Non-Chinese family & 34 & 6.53 & 42.66 & \\
\hline \multirow{2}{*}{ China CPC } & Chinese family & 67 & 3.33 & 55.48 & \multirow{2}{*}{$0.019 *$} \\
\cline { 2 - 6 } & Non-Chinese family & 34 & 1.56 & 42.18 & \\
\hline \multirow{2}{*}{ Total CPC } & Chinese family & 67 & 12.01 & 55.88 & \multirow{2}{*}{$0.018 *$} \\
\cline { 2 - 6 } & Non-Chinese family & 34 & 8.09 & 41.38 & \\
\hline
\end{tabular}

Table 9: Company controllers' backgrounds, total assets and capitalisation

business as personal and familial property, to hold fast to their controlling power. ${ }^{72}$ It would be interesting to find out if these influential corporations in Hong Kong seek more CPC to secure their power than other companies.

U-test was performed on the non-parametric data of the CPC degrees of the 67 Chinese-family companies and 34 non-Chinese family companies. Table 9 indicates a significant difference between the CPC levels of the Chinese family and non-Chinese family company groups as measured by their aggregate CPC scores in Hong Kong and China $(p=$ $0.018^{*}$ ). When regional connections are considered separately, the test similarly yields significant CPC differences between the two groups in both Hong Kong $\left(p=0.040^{*}\right)$ and China $\left(p=0.019^{*}\right)$. In all these three findings, the Chinese family company group shows higher mean CPC scores than its counterpart.

Why are Chinese family businesses more connected with politics? The above-mentioned assumption of their eagerness to maintain control over familial property can be a good explanation. Such eagerness could originate from the Chinese cultural emphasis on familial loyalty, a philosophical concept raised by Confucius that has moulded the thinking and behaviour of the Chinese people for thousands of years. In brief, the Confucian ideal of family is a paternal hierarchy, where the forefather is the source of authority over a large extended family system, where filial piety towards parents and ancestors and loyalty to family and even clan members are central values, and where the needs and glory of the family have priority over those of the individuals. ${ }^{73}$ The Confucian ethic seems to have extended to other social contexts as well. Chinese businesspeople would strive to protect their family businesses and make sure that they do not fall into the hands of non-family members. Ruskola further points out that the kinship logic of Chinese family firms is against the individual personality of corporations stressed by the Western 'nexus of contract' theory. In Chinese societies, clan corporations justify their profit-seeking at the expense of others by emphasising their fiduciary duties to maximise the collective interests of their families and extended families. ${ }^{74}$

Besides the ideological-philosophical background of the Chinese, the traditional low social status of business people in China also plays a role. First, they were not as influential as landlords or farmers in the old days, when the economy relied heavily on farmland and agriculture. Apart from farmers, scholars were respected for their knowledge, and craftsmen for their skills. Merchants, however, were perceived by the general public as selfish and

72 Lawton, 'Berle and Means' (n 22) 372; Lawton, 'Modelling' (n 21) 266.

73 A N Licht, 'Legal Plug-Ins: Cultural Distance, Cross-Listing, and Corporate Governance Reform’ (2004) 22 Berkeley Journal of International Law, 195, at 214-5.

74 T Ruskola, 'Conceptualizing Corporations and Kinship: Comparative Law and Development Theory in a Chinese Perspective’ (2000) 52 Stanford Law Review, 1599, at 1607. 


\begin{tabular}{|c|c|c|c|c|c|c|c|}
\hline \multirow{2}{*}{$\begin{array}{l}\text { More regulated } \\
\text { industries (no of } \\
\text { companies = 52) }\end{array}$} & \multicolumn{3}{|c|}{ HK СРC } & \multicolumn{3}{|c|}{ China CPC } & \multirow{2}{*}{$\begin{array}{l}\text { Total } \\
\text { CPC }\end{array}$} \\
\hline & D & ID & $\begin{array}{l}\text { Sub- } \\
\text { total }\end{array}$ & D & ID & $\begin{array}{l}\text { Sub- } \\
\text { total }\end{array}$ & \\
\hline $\begin{array}{l}\text { Public utilities and } \\
\text { transportation (5) }\end{array}$ & 5.20 & 8.40 & $\# 13.60$ & 2.80 & 0.00 & 2.80 & \#16.40 \\
\hline $\begin{array}{l}\text { Properties and } \\
\text { construction (22) }\end{array}$ & 3.86 & 5.23 & 9.09 & 2.82 & 1.59 & 4.64 & 13.73 \\
\hline Financials (17) & 3.82 & 5.18 & 9.24 & 0.24 & 1.88 & 2.12 & 11.35 \\
\hline Communications (8) & 2.25 & 7.13 & 9.38 & 0.38 & 1.38 & 1.75 & 11.13 \\
\hline Average & 3.73 & 5.81 & *9.62 & 1.60 & 1.50 & *3.19 & *12.81 \\
\hline \multirow{2}{*}{$\begin{array}{l}\text { Less regulated } \\
\text { industries (no of } \\
\text { companies }=49 \text { ) }\end{array}$} & \multicolumn{3}{|c|}{ HK CPC } & \multicolumn{3}{|c|}{ China CPC } & \multirow{2}{*}{$\begin{array}{l}\text { Total } \\
\text { CPC }\end{array}$} \\
\hline & D & ID & $\begin{array}{l}\text { Sub- } \\
\text { total }\end{array}$ & D & ID & $\begin{array}{l}\text { Sub- } \\
\text { total }\end{array}$ & \\
\hline $\begin{array}{l}\text { Conglomerates and } \\
\text { others (18) }\end{array}$ & 5.20 & 8.40 & \#13.60 & 2.80 & 0.00 & 2.80 & $\# 16.40$ \\
\hline $\begin{array}{l}\text { Hotels and } \\
\text { entertainment (9) }\end{array}$ & 3.86 & 5.23 & 9.09 & 2.82 & 1.59 & 4.64 & 13.73 \\
\hline $\begin{array}{l}\text { Industrial and } \\
\text { consumer products } \\
(22) \\
\end{array}$ & 3.82 & 5.18 & 9.24 & 0.24 & 1.88 & 2.12 & 11.35 \\
\hline Average & 2.25 & 7.13 & 9.38 & 0.38 & 1.38 & 1.75 & 11.13 \\
\hline
\end{tabular}

Table 10: More regulated industries v less regulated industries and their CPC scores in Hong Kong and China $(D=$ executive and non-executive directors; $\mathrm{ID}=$ independent directors)

corrupt, making profit out of exploitation. There were in general four social classes in ancient China. From top to bottom these were: scholars, farmers, craftsmen and merchants, with merchants ranking lowest on the four-tier social ladder. ${ }^{75}$ Because of Chinese merchants' inferior social status in past history, their traditional fear of and great respect for government officials in the highly hierarchical society, and their adherence to political power for raised social status and, more importantly, protection of business, especially family business, all these point to a greater need for political connection in Chinese family companies than other companies.

\section{(b) Hypothesis 2 confirmed}

\section{H2: Chinese family companies have more CPC than other companies.}

The test comparing the CPC level of Chinese family companies verses non-Chinesefamily companies shows that Chinese family businesses do have more CPC - in Hong Kong, in China and in Hong Kong and China as a whole - than the other companies. H2 is also confirmed.

\section{CPC AND GOVERNMENT REGULATION}

Referring to the definitions used by the HSICS, the 101 companies were categorised into seven industry types under the more regulated and less regulated group as shown in Table 10.

75 D Twitchett, 'A Confucian's View of the Taxation of Commerce: Ts'ui Jung's Memorial of 703' (1973) 36(2) Bulletin of the School of Oriental and African Studies, University of London 429, at 438. 


\begin{tabular}{|l|l|c|c|c|c|}
\hline & \multicolumn{1}{|c|}{ Industries } & Count & Mean CPC score & Mean rank & $p$ \\
\hline \hline \multirow{2}{*}{ HK CPC } & $\begin{array}{l}\text { More regulated } \\
\text { industries }\end{array}$ & 52 & 9.62 & 56.63 & \multirow{2}{*}{$0.044^{*}$} \\
\cline { 2 - 5 } & $\begin{array}{l}\text { Less regulated } \\
\text { industries }\end{array}$ & 49 & 6.20 & 45.02 & \multirow{2}{*}{0.169} \\
\hline \multirow{2}{*}{ China CPC } & $\begin{array}{l}\text { More regulated } \\
\text { industries }\end{array}$ & 52 & 3.19 & 54.59 & \multirow{2}{*}{$0.044^{*}$} \\
\cline { 2 - 5 } Total CPC & $\begin{array}{l}\text { Less regulated } \\
\text { industries }\end{array}$ & 49 & 2.24 & 47.19 & 56.67 \\
\hline
\end{tabular}

Table 11: Difference in degree of CPC between more regulated and less regulated industries

\section{(a) More and less regulated companies}

Table 10 shows that the industries under more government regulations (regarding entry into industry, licence conditions, licence renewal etc.) have higher average Hong Kong, China and total CPC scores than industries under fewer regulations (scores with ${ }^{*}$ ).

Among the more regulated industries, 'public utilities and transportation' has the highest Hong Kong CPC score as well as total CPC score (score with \#). This is a reasonable outcome as the industry is composed of monopolised companies of natural resources and public transportation such as Hong Kong and China Gas, China Light and Power Holdings, and MTR Corporation. These companies are subject to the strictest regulations that govern their price-setting and limit their profit boundaries. Since they are so stringently controlled by the local legislature, Hong Kong CPC becomes paramount for them to increase their say in shaping relevant policies in the Executive Council, Legislative Council and policy consultative bodies.

Table 10 also shows that 'properties and construction' has the highest average China CPC score among all the highly regulated industries. An explanation for this can be found in the annual reports of these companies. For example, the largest property developer in Hong Kong, Cheung Kong Holdings had 20 new acquisition and joint development projects in 2005, seven (i.e. over one-third) of them were in Mainland China. ${ }^{76}$ In the same year, the company had 21 properties under development in Hong Kong but 44 (i.e. more than twice those in Hong Kong) in Mainland China. The second largest local property developer, Sun Hung Kai Properties Ltd reported that its Hong Kong land bank in the financial year of 2005/2006 was $42.4 \mathrm{~m} \mathrm{ft} 2$, which is a slight growth of 1.2 per cent compared with the previous financial year. Within the same period, its China land bank was $19.8 \mathrm{~m} \mathrm{ft} 2$, a massive 132.9 per cent increase from the previous year. ${ }^{77}$ These figures show a clear trend of rapid business expansion of the property development sector from Hong Kong to Mainland China. Given the limited land resources in Hong Kong, such a development direction is inevitable. This makes CPC in China strategically important for the Hong Kong properties and construction industry.

\footnotetext{
76 Annual Report 2005 (Cheung Kong (Holding) Ltd 2006) <www.ckh.com.hk/ eng/investor/annual/2005eng.pdf $>$.

77 Annual Report 2005/2006 (Sun Hung Kai Properties Ltd 2006) <http://shkp.com/data/ investors/reports_detail/7/7/7_152_en.pdf $>$.
} 
Finally, Table 11 indicates that for each of the seven industries, more and less regulated ones alike, Hong Kong CPC scores are consistently higher than their corresponding China CPC scores. Notwithstanding the growing impact of Chinese politics on Hong Kong businesses after the change of sovereignty in 1997, Hong Kong public and corporate policies, after all, have the most direct and determining influence on companies based in Hong Kong. Hong Kong CPC is therefore the primary means of political connection for more regulated corporations in Hong Kong.

U-test results comparing the more regulated and less regulated company groups shown in Table 11 above confirms that the higher level of Hong Kong and total CPC scores of more regulated industries are statistically significant at the same level of 4.4 per cent. China CPC scores between the two groups are, however, not significantly different. As explained in the previous paragraph, more regulated industries are under strict local regulations. While they have the tendency of building somewhat more China CPC than less regulated industries as an indirect means of influencing local regulations, at the same time they naturally seek significantly more Hong Kong CPC than the less regulated group to directly protect their business interests.

\section{(b) Hypothesis 3 partially confirmed}

\section{H3: more regulated industries have more CPC than less regulated ones.}

Findings show that more regulated industries have significantly higher Hong Kong CPC and total CPC levels than less regulated ones. But the difference in the China CPC level between the two groups is insignificant, showing that industries subject to strict local regulations are more obviously reliant on local CPC than CPC with the mainland government. $\mathrm{H} 3$ is partially confirmed.

\section{Implications}

\section{CPC AS A NEW APPROACH TO UNDERSTANDING CORPORATE GOVERNANCE}

In recent years, politics has played an increasingly important role in corporate governance. Especially after the financial crises in 1998 and 2008, the market economy has become more in need of government intervention for stimulation and assistance. ${ }^{78}$ Companies are also playing a more public role in society. Not only do they have clearly defined public responsibilities and purposes recognised by law, but society also expects them to be accountable to the public for their actions. In this sense, they are both private associations and public bodies. ${ }^{79}$ This public role is intensified under globalisation, with international commercial arrangements often decided by multinational enterprises rather than governments alone. The new world trade order displays the dual role of corporations as

78 For example, as at February 2009, the US government has put US\$789bn into rescuing the market, which exceeds the entire cost of the Iraq War fought since 2003. G Hitt and J Weisman, 'Congress Strikes 789 Billion Stimulus Deal', Wall Street Journal, 12 February 2009, A1. In September 2008, a rumour spread by text message triggered a brief run on the Bank of East Asia as depositors feared that the bank in Hong Kong had large exposures to Lehman Brothers and AIG. The government in response guaranteed from October 2008 through year-end 2010 the repayment of all customer deposits held in all banks and authorised financial institutions in Hong Kong. The guarantee, which was backed by the government's Exchange Fund, applied to both Hong Kong-dollar and foreign-currency deposits, including those held in Hong Kong branches of overseas institutions. The original protected sum was HK\$100,000 (US\$12,898) per depositor per banking institution. 'Recent Developments in Asian Deposit Guarantee Programs' (2008) Asia Focus, Country Analysis Unit, Federal Reserve Bank of San Francisco <www.frbsf.org/ publications/banking/asiafocus/2008/Asia_Focus_Deposit_Insurance_Oct_08.pdf>.

79 A Gamble and G Kelly, 'The Politics of the Company' in J Parkinson et al (ed), The Political Economy of the Company (Portland 2001), 27. 
both private and public commercial actors in the political, social and economic arenas. ${ }^{80}$ The complex interactions between government and corporations and the connections between the political and business sectors are topics of growing relevance to the contemporary world, especially when they affect corporate governance at both micro and macro levels.

This is particularly true in Hong Kong. Since the 1997 handover to China, the fight for universal suffrage among democrats, the growing dissatisfaction of the public towards the Hong Kong and mainland governments and the frequent protests of various sectors of the society, all show that Hong Kong society is increasingly politicised. Even the government acknowledged the fact and introduced the political appointments system of senior officials in 2002 to help tackle political issues. ${ }^{81}$ Both political authorities and corporations need to handle CPC shrewdly and diplomatically and make necessary adjustments in order to meet public demands.

As shown from the above quantitative analysis, large-scale companies, Chinese family companies, and more regulated companies are proved to have more CPC than the respective opposite company groups. These three types of companies share a common feature. They are all the most influential companies in that they have more resources, dominate the local business sector, and/or belong to industries that have the greatest impact on the daily lives of the general public. In other words, the most influential companies in Hong Kong are also companies that are most connected politically by taking up official positions and by informal contacts with political authorities. The combination of political and business power gives rise to privileged, excessively dominant business controllers who upset the power balance in corporate governance. The great contrast in power balance is reflected in the wide gap between the rich and the poor as shown by the high Gini score of Hong Kong. The United Nations Development Programme investigated income inequality worldwide in 2007 and reported that Hong Kong topped all other advanced economies as the region with the biggest gap between the rich and the poor. Hong Kong had a Gini score of 43.4, ${ }^{82}$ with the richest 10 per cent of the population receiving 34.9 per cent of the city's total income but the poorest 10 per cent sharing only 2 per cent of it. ${ }^{83}$ The government cannot afford to lose control of the development of CPC, or serious problems in companies and in society as a whole can be expected.

\section{RE-EXAMINATION OF CORPORATE GOVERNANCE THEORIES}

Besides pointing to a new approach to understanding corporate governance, the results of this study have also helped to re-examine some of the existing corporate governance theories.

\section{(a) Market thesis}

The market thesis predicts that as a company develops or the market matures, shareholding will break up through inheritance or issues of more securities, resulting in the market gradually changing towards diffuse ownership. ${ }^{84}$ Berle and Means consider dispersed ownership a natural product of market force; for as corporations expand, they require an

80 B Ahunwan, Globalisation and Corporate Governance in Developing Countries (Transnational Publishers Inc 2003), 35.

81 D Tsang, Press Release, 'Chief Secretary's Speech', 18 March 2002 <www.info.gov.hk/gia/general/200203/ 18/0318152.htm>.

82 The Gini coefficient is named after the Italian statistician, Corrado Gini, with zero signifying absolute income/wealth equality and 1 absolute inequality. In the United Nations Development Programme report, Gini scores range from 0 (absolute income equality) to 100 (absolute income inequality).

83 B Einhorn, 'Countries with the Biggest Gaps between Rich and Poor', Business Week, 16 October 2009.

84 See Berle and Means (n 61) 66; and Leech (n 64) 537. 
increasing amount of capital that exceeds the resources of any single individual or family 85 and that can only be raised through selling shares to numerous small investors. ${ }^{86} \mathrm{~A}$ diffused ownership structure is necessitated for large public corporations due to the demand for more capital to meet market competition.

From a market perspective, Hong Kong is equipped with most requisites for a dispersed system. First of all, it is a highly developed economy. Its gross national income (GNI) per capita ranked 28th in the world in 2005. ${ }^{87}$ Hong Kong stock market's capitalisation ranked seventh and third in the world and Asia respectively in 2009.88 As for corporate governance, in spite of all the aforesaid problems related to its concentrated family business model, Hong Kong has maintained a relatively high standard in its legal and corporate governance systems among countries practising ownership concentration. ${ }^{89}$ However, as seen from the statistical evidence of this study, Hong Kong is a sophisticated market with a vast majority of highly concentrated companies. The empirical finding shows that existing theories, especially those developed in the context of the US/UK markets, may not be applicable to Hong Kong and other countries.

As observed by La Porta et al, the diffuse corporate ownership of the US/UK is highly exceptional. Outside of the two countries, large firms usually have ultimate controlling owners. ${ }^{90}$ Morck et al's study further confirms that most large corporations in the world are controlled by very wealthy families. It is common for them to have super voting rights, pyramidal control and cross shareholding, through which they can control a considerable proportion of a country's economy. ${ }^{91}$ For instance, in Hong Kong, the Chinese family businesses have their cultural and psychological persistence in corporate ownership. No matter how developed the market is, it is not easy for them to transform into diffuse ownership. It follows that the convergence theory (i.e. the prediction that all economies will converge into the US/UK diffuse ownership model) is unlikely to be realised through market adjustments. An ideological metamorphosis of most countries is a prerequisite if the theory is possible at all.

\section{(b) Law thesis}

La Porta et al argue that the quality of law is a robust determinant of ownership patterns. ${ }^{92}$ Their study reveals that there is positive correlation between good legal minority shareholder protection and dispersed ownership and vice versa. ${ }^{93}$

However, this correlation does not apply to Hong Kong. Hong Kong has relatively good legal minority shareholder protection. In the Corporate Governance Index of FTSE Institutional Shareholder Services (ISS), Hong Kong ranks fourth among 24 markets in the world and the first among the Asian markets. It ranks just slightly lower than Singapore in

85 Berle and Means (n 61) 59.

86 Ibid 2-7.

87 World Bank, 2006 <http://siteresources.worldbank.org/DATASTATISTICS/Resources/GNIPC.pdf>.

88 Market Capitalisation of the World's Top Stock Exchanges (Securities and Futures Commission 2007) $<$ www.sfc.hk/sfc/doc/EN/research/stat/a01.doc>.

89 C K Low, 'A Road Map for Corporate Governance in East Asia' (2004) 25 Northwestern Journal of International Law and Business 165, at 168.

90 La Porta et al (n 62) 471-517.

91 Morck et al (n 66) 657.

92 La Porta et al (n 62) 511.

93 Ibid 505-11. 
terms of corporate governance culture and international audit and accounting standards. ${ }^{94}$ It also ranks in the top quartile on the World Bank's rule of law index in 2004 and 2009. 95 Yet, Hong Kong has remained an economy of highly concentrated ownership, as suggested by the findings reported in this article.

La Porta et al also suggest that the common law system has more minority shareholder protection and that good minority protection is correlated with dispersed ownership. ${ }^{96}$ The presumed link between the common law system and dispersed ownership concentration is contradictory to the real situation of Hong Kong, which has inherited the British common law system since its colonisation more than a hundred years ago.

This CPC study suggests a new perspective for ownership concentration and corporate governance. Although the overall concentration pattern of Hong Kong companies under the common law system remains high, the ownership of CPC companies is proved to be statistically less concentrated than that of non-CPC companies. In the context of CPC companies, less concentrated corporate structure does not necessarily guarantee more minority shareholder protection because controlling shareholders exist in almost all of these less concentrated companies.

The fact that corporate governance cannot benefit from a reduced yet still high concentration level in CPC companies points to two interesting questions. First, is there a threshold or optimum point on the concentration continum to be crossed for any economies to function as effectively as the US/UK model? And even if there is, is the US/UK model really the best model to be pursued by any countries? While the first question is worth more research efforts in the area, the answer to the second question seems to be negative, judging from the results of this study.

The transplantation of a legal system is not equivalent to transplanting the legal spirit. Borrowing laws and regulations from the Anglo-American and common law systems does not guarantee dispersed ownership or good law. If the implanted laws contradict local values, customs and existing institutional make-up, the laws are likely to be changed or twisted to suit local needs. ${ }^{97}$ Therefore, when the same legal system is introduced to other countries, different outcomes can be expected.

\section{(c) Politics thesis}

The political theory developed by Roe suggests that the political reaction of majority shareholders to the demand of government for social equality and stable employment in social democratic European countries has resulted in the persistent concentrated ownership, which helps majority shareholders to gain more control to resist the political pressure of raising costs and foregoing profit-maximising opportunities for social causes. ${ }^{98}$ The theory is obviously inapplicable to the Hong Kong case, which is quite opposite to the example raised by Roe.

Hong Kong has a non-democratic government and controlling shareholders' interests are not in conflict with those of the government. The controlling shareholders do not resist

94 The rankings of ACGA and ISS are quoted from the speech of M Wheatley, 'Corporate Governance' (Securities and Futures Commission 2006) <www.sfc.hk/sfc/doc/EN/general/general/press_release/06/ mw_060116_hkiod.pdf>.

95 'Worldwide Governance Indicators Country Snapshot' (World Bank 2011) <http://info.worldbank.org/governance/wgi/sc_country.asp>.

96 R La Porta et al, 'Law and Finance' (1998) 52 Journal of Finance 1131, at 1138.

97 K Pistor et al, 'The Evolution of Corporate Law: A Cross-Country Comparison' (2002) 23 University of Pennsylvania Journal of International Economic Law 791, at 797.

98 Roe (n 17) 539, 543 and 594. 
but actively participate in politics and cooperate with the government as far as possible in exchange for political benefits. Such reaction does not result in further increasing their shareholding but in the political phenomenon of CPC. As found by the statistical analysis of the study, CPC companies have significantly less concentrated ownership than non-CPC companies. It is probably because CPC companies have available political channels to maintain their controlling power through CPC. In sharp contrast to Roe's theory, the political reaction of controlling shareholders in Hong Kong is associated with lower rather than higher ownership concentration. However, a commonality of the European and Hong Kong cases is that politics does make a difference in corporate ownership structure.

Previous approaches to the study of corporate governance are largely confined by the market thesis, the law thesis and the politics thesis which do not recognise the potential significance of CPC. CPC could be a new approach to understanding the political aspects of corporate governance and exploring solutions to related problems.

\section{Conclusion}

This article has explored the characteristics of CPC companies in Hong Kong in relation to their corporate structure, Chinese ownership background and industry type. In general, CPC companies tend to be larger in scale, and companies with Chinese family ownership and in more regulated industries tend to have a higher degree of political connection. The study attempts to anatomise the complex issue of political connection established by companies and contends that past theories and approaches are inadequate to deal with corporate governance problems. Hong Kong, as do other countries in the world, has its own unique and complex social backgrounds and conditions. The simple convergence of law is not penicillin for every economy. The world needs to adopt a more political perspective that takes into account the interaction of cultural, historical, legal and political factors. The study of CPC as a determinant of corporate governance provides a possible direction for future research on corporate governance in Hong Kong and elsewhere. 
